\title{
Primary Structure of Selected Archaeal Mesophilic and Extremely Thermophilic Outer Surface Layer Proteins
}

\author{
Harald Claus ${ }^{1}$, Erol Akça ${ }^{1}$, Tony Debaerdemaeker ${ }^{2}$, Christine Evrard ${ }^{3}$, Jean-Paul Declercq ${ }^{3}$ and Helmut König ${ }^{1}$ \\ ${ }^{1}$ Institut für Mikrobiologie und Weinforschung, Johannes Gutenberg-Universität, Mainz, Germany \\ ${ }^{2}$ Sektion Röntgen- und Elektronenbeugung, Universität Ulm, Ulm, Germany \\ ${ }^{3}$ Laboratoire de Chimie et de Cristallographie, Université Catholique de Louvain, Louvain-la-Neuve, Belgium
}

\begin{abstract}
Summary
The archaea are recognized as a separate third domain of life together with the bacteria and eucarya. The archaea include the methanogens, extreme halophiles, thermoplasmas, sulfate reducers and sulfur metabolizing thermophiles, which thrive in different habitats such as anaerobic niches, salt lakes, and marine hydrothermals systems and continental solfataras. Many of these habitats represent extreme environments in respect to temperature, osmotic pressure and $\mathrm{pH}$-values and remind on the conditions of the early earth. The cell envelope structures were one of the first biochemical characteristics of archaea studied in detail. The most common archaeal cell envelope is composed of a single crystalline protein or glycoprotein surface layer (S-layer), which is associated with the outside of the cytoplasmic membrane. The S-layers are directly exposed to the extreme environment and can not be stabilized by cellular components. Therefore, from comparative studies of mesophilic and extremely thermophilic S-layer proteins hints can be obtained about the molecular mechanisms of protein stabilization at high temperatures. First crystallization experiments of surface layer proteins under microgravity conditions were successful. Here, we report on the biochemical features of selected mesophilic and extremely archaeal S-layer (glyco-) proteins.
\end{abstract}

Keywords : Archaea ; cell walls ; S-layer ; (glyco-)proteins ; protein structure

\section{INTRODUCTION}

During evolution cellular organisms developed cell walls which improved the rigidity and integrity of their cells and probably enabled them to colonize new biotopes. Regular crystalline surface layers (S-layers) are widespread among prokaryotes and it seems that they are probably the earliest cell wall structures (BAUMEISTER and LEMBCKE, 1992; BEVERIDGE and GRAHAM, 1991; ENGEL-HARDT and PETERS, 1998; KANDLER and KÖNIG, 1985, 1993; KÖNIG and MESSNER, 1997; MESSNER and SLEYTR, 1992; SuMPER and WIELAND, 1995). The crystallization on the cell surface is an entropy driven process and requires no enzymatic acitivity. Two dimensional crystalline protein or glycoprotein arrays (S-layers) represent the outermost cell wall layer in about 350 different so far investigated species of the prokaryotic domains bacteria and archaea. S-layers consist of single (glyco-)protein species with molecular masses ranging from about 40 to $170 \mathrm{kDa}$, which form lattices of oblique, tetragonal or hexagonal architecture. Depending on the growth conditions some microorganisms can also produce different surface proteins (BAUMEISTER and LEMBCKE, 1992; BEVERIDGE and KOVAL, 1993; BOOT and Pouwels, 1996; EgElseER et al., 2001; KÖNIG and MESSNER, 1997; MESSNER and SLEYTR, 1992).

Structural differences might be found as a consequence of post-translational modifications such as glycosylation, transfer of phosphate and sulfate groups or proteolytic processing of the proteins (SÁRA and SLEYTR, 2000; SCHÄFER and MESSNER, 2001; SLEYTR, 1997). With a few exceptions, which include lac-tobacilli and the archaea Methanothermus fervidus and Methanothermus sociabilis (BRÖCKL et al., 1991), S-layer proteins have weakly acidic isoelectric points (SÁRA and SLEYTR, 2000; SLEYTR, 1997).

Depending on their location on the cell surface and their stability S-layers fulfill quite different functions. They form protective coats, maintain the shape and direct cell division, function as molecular sieves and attachment sites for extracellular enzymes and, represent virulence factors (BEVERIDGE et al., 1997, SLEYTR and BEVERIDGE, 1999). Representing the outermost cell envelope layer they are directly exposed to the often extreme conditions of their environment. As a consequence, intrinsic resistances against environmental stresses like high salt, acidity and temperature should be attributed to archaeal S-layers. The molecular mechanisms for this high stability are 
only poorly understood. For example, members of the genus Metbanococcus living in mesophilic, thermophilic or extremely thermophilic environments represent an ideal model system for comparative analyses of their Slayers as a focus for thermal adaption (AKÇA et al., 2002). It became obvious that the diversity of the archaea is also reflected in a remarkable diversity of cell envelope types (Table 1). It was the aim of this study to compare the biochemical characteristics of selected archaeal S-layer proteins living under different environmental conditions. The knowledge of the threedimensional structure is a prerequisite to understand the molecular mechanisms of protein stabilization under extreme conditions. Therefore, we decided to propose this proteins for microgravity crystallization experiments.

Table 1. Diversity of archaeal cell envelope types.

\begin{tabular}{|c|c|c|}
\hline Selected Archaeal Genera & Cell Envelope Types & References (selection) \\
\hline \multicolumn{3}{|l|}{ Extreme Halophiles } \\
\hline Haloarcula & S-layer & WAKAI et al., 1997 \\
\hline Halobacterium & S-layer & LECHNER and SUMPER, 1987 \\
\hline Halococcus & heteropolysaccharide & SCHLEIFER et al., 1982 \\
\hline Haloferax & S-layer & SUMPER et al., 1990 \\
\hline Natronococcus & glutaminylglycan & NIEMETZ et al., 1997 \\
\hline \multicolumn{3}{|l|}{ Methanogens } \\
\hline Methano bacterium & $\begin{array}{c}\text { pseudomurein/ } \\
\text { gene of S-layer protein }\end{array}$ & $\begin{array}{c}\text { KANDLER and KÖNIG, } 1978 \\
\text { AKÇA et al., } 2002\end{array}$ \\
\hline Methanobrevibacter & pseudomurein & KANDLER and KÖNIG, 1978 \\
\hline Methanococcus & S-layer & AKÇA et al., 2002 \\
\hline Methanocorpusculum & S-layer & ZELLNER et al., 1987 \\
\hline Methanoculleus & S-layer & BAYLEY and KOVAL, 1994 \\
\hline Methanogenium & S-layer & KANDLER and KÖNIG, 1978 \\
\hline Methanomicrobium & S-layer & KANDLER and KÖNIG, 1978 \\
\hline Methanolacinia & S-layer & ZELLNER et al., 1989 \\
\hline Methanolobus & S-layer & KÖNIG and STETTER, 1982 \\
\hline Methanoplanus & S-layer & WTILDGRUBER et al., 1982 \\
\hline Methanopyrus & pseudomurein & Kurr et al., 1991 \\
\hline Methanosaeta & sheath & PATEL AND SPROTT, 1990 \\
\hline Methanothrix & sheath & KANDLER and KÖNIG, 1985 \\
\hline Methanosarcina & $\begin{array}{l}\text { methanochondroitin/ } \\
\text { S-layer }\end{array}$ & $\begin{array}{c}\text { KREISL and KANDLER, } 1986 \\
\text { MAYERHOFER et al., } 1998\end{array}$ \\
\hline Methanosphaera & pseudomurein & KÖNIG, 1986 \\
\hline Methanospirillum & sheath & SOUTHAM et al., 1993 \\
\hline Methanothermus & pseudomurein/ & STETTER et al., 1981 \\
\hline & S-layer & BRÖCKL et al., 1991 \\
\hline \multicolumn{3}{|l|}{ Sulfate reducers } \\
\hline Archaeoglobus & S-layer & STETTER, 1992 \\
\hline \multicolumn{3}{|c|}{ Extremely thermophilic sulfur metabolizers } \\
\hline Acidianus & S-layer & BAUMEISTER et al., 1991 \\
\hline Desulfurococcus & S-layer & WILDHABER et al., 1987 \\
\hline Hyperthermus & S-layer & ZILLIG et al., 1990 \\
\hline Pyrodictium & S-layer & STETTER et al., 1983 \\
\hline Pyrobaculum & S-layer & PHIPPS et al., 1991 \\
\hline Pyrococcus & S-layer & FIALA and STETTER, 1986 \\
\hline Staphylothermus & S-layer & PETERS et al., 1995 \\
\hline Sulfolobus & S-layer & DEATHERAGE et al., 1983 \\
\hline Phermoproteus & S-layer & MESSNER et al., 1986 \\
\hline \multicolumn{3}{|l|}{ Thermoplasmas } \\
\hline Phermoplasma & Glycocalyx & YANG and HAUG, 1979 \\
\hline
\end{tabular}




\section{COMPARISON OF S-LAYERS OF MESOPHILIC, THERMOPHILIC AND EXTREMELY THERMOPHILIC ARCHAEA}

S-layer proteins of Methanococcus vannielii $\left(\mathrm{T}_{\mathrm{opt}}=37^{\circ} \mathrm{C}\right)$, Methanococcus thermolithotrophicus $\left(\mathrm{T}_{\mathrm{opt}}=65^{\circ} \mathrm{C}\right)$ and Methanococcus jannaschii $\left(\mathrm{T}_{\mathrm{opt}}=85^{\circ} \mathrm{C}\right)$ with the prominent bands of $60 \mathrm{kDa}, 82 \mathrm{kDa}$ and $80 \mathrm{kDa}$, respectively, on SDS-PAGE were investigated. (Table 2; AKÇA et al., 2002). Despite the high overall homology of the nucleotide sequences of the genes of the methanococcal S-layer proteins the deduced amino acid composition displayed some noteworthy differences (Table 3). In the mesophilic (Methanococcus voltae, Methanococcus vannielii) and thermophilic (Methanococcus thermolithotrophicus) methanococci e.g. the nonpolar amino acid alanine is the most abundant amino acid, whereas in the extreme thermophile Methanococcus jannaschii it is the acidic amino acid aspartic acid. In the latter species lysine residues mainly localized in non-conserved positions are also found in significant higher amounts compared to the mesophilic ones (Table 3). The occurrence of the amino acids cysteine and histidine is characteristic for the S-layer protein of Methanococcus jannaschii and they are not present in the other methanococci. Although no glycan residues could be detected by periodate-Schiff staining (PAS) in the S-layer proteins of methanococci, two potential Nglycosylation sites were found in the mesophilic methanogen Methanococcus voltae, five in the thermophilic methanogen Methanococcus thermolithotrophicus and eight in the extreme thermophilic species Methanococcus jannaschii, while sequon structures (N-glycosylation sites) were missing in Methanococcus vannielii. The sequon structures are located nearly at the same positions in the methanococcal S-layer proteins. A unique feature of the S-layer sequences investigated in this study is a putative $\mathrm{Ca}^{++}$-binding site in Methanococcus jannaschii predicted by the amino acid sequence DLDSGDEVDILDY.

The overall amino composition (Table 4) of archaeal S-layer proteins is characterized by the predominance of nonpolar amino acids (exception: Methanosarcina mazei), followed by polar and acid amino acids and a lower content of basic ones. An increase of charged residues is a common feature of the thermophilic and extremely thermophilic species compared to their mesophilic counterparts. Generally, the amount of glutamine and asparagine decreases in the thermophiles compared to the mesophiles (DAS and GERSTEIN, 2000). An exception are the S-layer glycoproteins of Methanothermus fervidus and Mt. sociabilis, which have a high content of asparagine (BRÖCKL et al., 1991). The S-layer proteins of the two mesophilic methanococci have more nonpolar residues resulting in a higher degree of hydropathic-ity than the corresponding (extremely) thermophilic methanococcal proteins. In this respect, the S-layer protein of the extreme thermophile Staphylothermus marinus revealed the highest hydropathicity value and that of the extreme halophile Halobacterium halobium the lowest one.

The calculated acidic isolelectric point (4.27) of the S-layer polypeptide from Methanococcus jannaschii (BULT et al., 1996) is in agreement with the results of the preparative isoelectric focusing. Also the S-layer proteins of Methanococcus vannielii and Methanococcus thermolithotrophicus focused at a similar acidic $\mathrm{pH}$. In contrast, the calculated pIs of the S-layer proteins of Methanothermus fervidus, Methanobacterium thermoautotrophicus (gene MTH719) and Methanosarcina mazei are in the range of 8.47 and 8.9 (Table 4).

A prediction of the deduced secondary structure indicated a higher content of helical structures in the S-layer proteins of the mesophilic species (Methanococcus voltae, Methanococcus vannielii) than in Methanococcus thermolithotrophicus and Methanococcus jannaschii, which in turn exhibit more loops (Table 5). Despite differences in the growth temperature similarities exist between the S-layer proteins of Methanococcus and Pyrococcus and between those of Archaeoglobus fulgidus, Methanothermus fervidus, Methanobacterium thermoautotrophicus (gene MTH719) and Methanosarcina mazei. Since halobacteria are adapted to high salt, similarities between the S-layer proteins of methanococci and halobacteria could not be expected.

The presumptive leader peptides (ca. 30 amino acids) of the S-layer proteins (e.g. methanococci; AKÇA et al., 2002) showed the typical characteristics of a signal sequence with a positively charged $\mathrm{N}$-region, a hydrophobic core, a polar C-region and an alanine residue at the peptide cleavage site (NIELSEN et al., 1997). Furthermore, the alignments revealed a notable degree of homology between the S-layer genes of the mesophilic up to the extremely thermophilic methanococci (Table 6) especially at the N- and C-termini. Surprisingly, the S-layer genes of the methanococci shared a significant homology with the presumptive S-layer genes of the extremely thermophilic heterotrophs Pyrococcus abyssi and Pyrococcus hori-kosbi.

The S-layer proteins of Methanosarcina mazei (mesophilic) and the gram-positive methanogens Methanobacterium thermoautotrophicum (thermophilic), Methanothermus fervidus (extremely thermophilic) and Methanothermus sociabilis (extremely thermophilic) possess a significant degree of similarity. They have the conserved sequence I-Q-[E/A]-A-I-D in common. The S-layer proteins of these species and that of the sulfate- 
reducing Archaeoglobus fulgidus (extremely thermophilic) also shared high similarities in the amino acid sequence. No relationship of the latter species and the halobacteria was found with the methanococci or with the extremely thermophilic sulfur-dependent species Staphylothermus marinus.

Table 2. S-layer genes and proteins from selected mesophilic and thermophilic archaea used for sequence comparisons.

\begin{tabular}{|c|c|c|c|c|c|c|}
\hline Species & $\begin{array}{c}\text { Growth } \\
\text { optimum } \\
\left({ }^{\circ} \mathrm{C}\right)\end{array}$ & $\begin{array}{c}\text { Accession No. } \\
\text { (gene designation) }\end{array}$ & Size (aa) & $\begin{array}{c}\text { Molecular } \\
\text { mass } \\
\text { (Daltons) }\end{array}$ & $\begin{array}{l}\text { N-glycosylation } \\
\text { sites }\end{array}$ & $\begin{array}{c}\text { Glycosylation } \\
\text { detected }^{2)}\end{array}$ \\
\hline \multirow[t]{2}{*}{ Archaeoglobus fulgidus } & 85 & AF0275 $(s \lg b-1)$ & [914] & [99221] & [4] & + \\
\hline & & AF1413 (slgb-2) & [2425] & {$[266571]$} & {$[45]$} & \\
\hline Haloarcula japonica & 37 & $\mathrm{D} 87290(\operatorname{csg})$ & 890 & 89814 & 6 & + \\
\hline Halobacterium halobium & 37 & J02767 (csg_HALHA) & 852 & 89814 & 7 & + \\
\hline Haloferax volcanii & 37 & M62816 (csg_HALVA) & 827 & 85189 & 13 & + \\
\hline Methanobacterium & 65 & AAB85224 (MTH719) & {$[574]$} & [61922] & {$[25]$} & n.d \\
\hline \multirow[t]{2}{*}{ thermoautotrophicum } & & AAB85221 (MTH716) & [1755] & {$[191961]$} & {$[72]$} & \\
\hline & & AAB85988 (MTH1513) & [1408] & {$[152737]$} & [38] & - \\
\hline $\begin{array}{l}\text { Methanococcus } \\
\text { jannaschii }\end{array}$ & 85 & $\mathrm{AJ} 311636^{3)}(\operatorname{slmj} 1)$ & 558 & 60547 & 8 & - \\
\hline $\begin{array}{l}\text { Methanococcus } \\
\text { thermolithotrophicus }\end{array}$ & 65 & $\mathrm{AJ} 308554^{3 \prime}(\operatorname{slm} t 1)$ & 559 & 59225 & 5 & - \\
\hline Methanococcus vannielii & 37 & $\mathrm{AJ} 308553^{3)}(\operatorname{slm} v 1)$ & 550 & 57546 & n.f. & - \\
\hline Methanococcus voltae & 37 & M59200 (sla) & 565 & 59707 & 2 & \\
\hline Methanosarcina mazei & 37 & $\mathrm{X} 77929(\operatorname{slg} B)$ & {$[652]$} & {$[68878]$} & {$[11]$} & n.d. \\
\hline $\begin{array}{l}\text { Methanothermus } \\
\text { fervidus }\end{array}$ & 85 & $\mathrm{X} 58297(\operatorname{slg} A)$ & 593 & 65481 & & \\
\hline $\begin{array}{l}\text { Methanothermus } \\
\text { sociabilis }\end{array}$ & 85 & $\mathrm{X} 5 \mathrm{~S} 296(\operatorname{slg} A)$ & 593 & 65481 & 19 & + \\
\hline Pyrococcus abyssi & 97 & $\begin{array}{l}\text { NT01PA0829 } \\
\text { (PAB1861) }\end{array}$ & [604] & {$[65985]$} & n.f. & n.d. \\
\hline Pyrococcus horikoshii & 95 & NT01PH1418 (PH1395) & [236] & [26128] & n.f. & n.d. \\
\hline $\begin{array}{l}\text { Staphylothermus } \\
\text { marinus }\end{array}$ & 92 & U57967 & 1524 & 166287 & 61 & + \\
\hline
\end{tabular}

${ }^{1)}$ predicted by PROSITE; ${ }^{2}$ PAS-staining, + positive, - negative; ${ }^{3)}$ deposited with the EMBL nucleotide sequence data base; [ ]: open reading frame of a presumptive coding region of an S-layer gene; n.d. not determined; n.f. not found.

Table 3. Amino acids (aa) composition of selected archaeal S-layer proteins (mol\%).

\begin{tabular}{lcccccccccccccc} 
Ala & 14.0 & 16.0 & 12.2 & 9.9 & 8.3 & 6.8 & 6.7 & 6.1 & 4.4 & 5.1 & 5.2 & 7.8 & 7.2 & 8.1 \\
& & & & & & & & & & & & & \\
Arg & 0.5 & 1.1 & 1.3 & 0.7 & 0.8 & 1.7 & 1.5 & 3.7 & 2.9 & 4.0 & 2.2 & 2.1 & 2.3 & 1.8 \\
Asn & 4.6 & 5.6 & 5.0 & 5.6 & 4.6 & 2.5 & 9.8 & 11.8 & 12.0 & 7.1 & 10.1 & 5.7 & 6.6 & 5.2 \\
Asp & 11.3 & 10.4 & 11.6 & 14.0 & 7.5 & 7.6 & 3.5 & 3.7 & 3.9 & 6.1 & 5.8 & 13.8 & 13.4 & 10.9 \\
Cys & - & - & - & 0.4 & 0.2 & 0.4 & 1.1 & 0.7 & 1.3 & 1.2 & 0.5 & 0.0 & 0.0 & 0.0 \\
Gln & 1.4 & 2.5 & 1.6 & 0.5 & 2.0 & 1.7 & 1.8 & 2.4 & 1.0 & 2.0 & 2.0 & 2.6 & 3.2 & 2.7 \\
\hline
\end{tabular}




\begin{tabular}{|c|c|c|c|c|c|c|c|c|c|c|c|c|c|c|}
\hline$\overline{\text { Glu }}$ & 7.3 & 4.4 & 6.3 & 6.5 & 7.5 & 10.6 & 1.7 & 2.4 & 5.2 & 6.8 & 3.3 & 9.7 & 8.2 & 8.1 \\
\hline Gly & 7.4 & 8.0 & 7.5 & 7.2 & 8.6 & 9.3 & 10.1 & 9.9 & 9.8 & 9.4 & 6.6 & 8.9 & 9.7 & 10.3 \\
\hline His & - & - & - & 0.5 & 0.3 & 0.4 & 1.1 & 0.9 & 0.2 & 1.4 & 0.8 & 0.4 & 0.2 & 0.2 \\
\hline Ile & 4.6 & 4.9 & 6.4 & 4.8 & 7.8 & 7.6 & 7.1 & 8.7 & 13.5 & 6.8 & 8.5 & 5.5 & 4.9 & 6.0 \\
\hline Leu & 8.8 & 7.6 & 7.9 & 8.6 & 6.6 & 8.5 & 4.6 & 7.5 & 4.7 & 5.9 & 10.8 & 5.6 & 5.6 & 6.4 \\
\hline Lys & 8.1 & 6.9 & 8.8 & 10.0 & 9.6 & 10.2 & 5.1 & 3.3 & 7.1 & 3.8 & 2.8 & 0.7 & 1.9 & 0.7 \\
\hline Met & 2.1 & 2.0 & 2.0 & 2.7 & 1.0 & 0.4 & 1.4 & 1.0 & 1.5 & 1.4 & 1.1 & 0.2 & 1.1 & 0.8 \\
\hline Phe & 2.5 & 3.3 & 1.8 & 1.8 & 3.8 & 2.5 & 2.1 & 2.8 & 2.7 & 3.6 & 3.6 & 4.0 & 2.2 & 1.8 \\
\hline Pro & 1.6 & 2.2 & 1.6 & 2.3 & 3.1 & 2.5 & 4.1 & 3.3 & 3.2 & 3.5 & 3.3 & 3.3 & 2.5 & 2.3 \\
\hline Ser & 5.5 & 5.1 & 6.3 & 4.1 & 4.5 & 3.4 & 12.4 & 6.6 & 6.2 & 10.0 & 7.2 & 8.5 & 9.0 & 10.5 \\
\hline Thr & 6.7 & 5.3 & 5.2 & 5.2 & 7.6 & 8.9 & 13.2 & 10.8 & 7.9 & 6.8 & 11.2 & 11.0 & 10.6 & 13.7 \\
\hline $\operatorname{Trp}$ & 0.5 & 0.9 & 0.5 & 0.7 & 1.3 & 1.3 & 2.0 & 0.9 & 1.3 & 1.2 & 0.9 & 0.2 & 0.2 & 0.4 \\
\hline Tyr & 3.4 & 2.9 & 2.9 & 4.1 & 4.8 & 5.5 & 5.1 & 5.2 & 5.7 & 5.7 & 4.5 & 2.0 & 2.7 & 1.9 \\
\hline Val & 9.6 & 10.5 & 11.1 & 10.4 & 10.1 & 8.1 & 5.5 & 8.2 & 5.4 & 8.2 & 9.6 & 7.9 & 8.5 & 8.1 \\
\hline
\end{tabular}

- not found; genus abreviations: cf. Table 6; aa - amino acids

Table 4. Characteristics of the amino acid composition of selected archaeal S-layer proteins.

\begin{tabular}{|c|c|c|c|c|c|c|c|}
\hline \multirow[t]{2}{*}{ Species } & \multicolumn{7}{|c|}{ Characteristics of amino acid composition } \\
\hline & Nonpolar $^{\mathrm{a}}$ & Polar $^{\mathrm{a}}$ & Acidic $^{a}$ & Basic $^{\mathrm{a}}$ & $\begin{array}{l}\text { Aliphatic } \\
\text { Index }^{\mathrm{b}}\end{array}$ & Hydropathicity $^{\mathrm{b}}$ & $\mathrm{pI}^{\mathrm{b}}$ \\
\hline Mc. voltae & 48.5 & 24.2 & 18.6 & 8.6 & 94.16 & -0.091 & 4.15 \\
\hline Mc. vannielii & 52.5 & 24.3 & 14.8 & 8.0 & 95.51 & 0.061 & 4.25 \\
\hline $\begin{array}{l}\text { Mc. } \\
\text { thermolithotrophicus }\end{array}$ & 48.5 & 23.5 & 17.9 & 10.1 & 100.14 & -0.079 & 4.30 \\
\hline Mc. jannaschii & 45.0 & 23.3 & 20.5 & 11.2 & 92.42 & -0.296 & 4.27 \\
\hline Ms. mazei & 40.2 & 46.8 & 5.2 & 7.7 & 68.22 & -0.315 & 8.9 \\
\hline $\begin{array}{l}\text { Mb. } \\
\text { thermoautotrophicum } \\
\text { MTH719 }\end{array}$ & 46.5 & 39.4 & 6.1 & 7.9 & 93.03 & -0.086 & 8.75 \\
\hline Mt. fervidus & 43.7 & 36.9 & 9.1 & 10.2 & 91.10 & -0.236 & 8.47 \\
\hline Ag. fulgidus AF 1413 & 43.9 & 34.0 & 12.9 & 9.2 & 72.28 & -0.331 & 4.68 \\
\hline St. marinus & 47.6 & 37.5 & 9.1 & 5.8 & 108.39 & 0.169 & 4.45 \\
\hline Hb. halobium & 40.6 & 33.4 & 21.6 & 4.4 & 72.86 & -0.543 & 3.60 \\
\hline Hf. haloferax & 43.0 & 35.2 & 19.0 & 2.7 & 80.17 & -0.275 & 3.44 \\
\hline Ha. japonica & 43.0 & 30.2 & 23.5 & 3.2 & 73.94 & -0.462 & 3.40 \\
\hline Pc. abysii & 48.3 & 26.0 & 15.0 & 10.7 & 93.74 & -0.119 & 4.68 \\
\hline Pc. horikoshii & 45.3 & 24.1 & 18.2 & 12.3 & 92.92 & -0.308 & 4.62 \\
\hline
\end{tabular}

${ }^{a}$ mol (\%) calculated after Karlson (1994); ${ }^{b}$ calculated with ProtPARAM Tool; genus abbreviation cf. Table 6

Table 5. Predicted secondary structures of archaeal S-layer proteins.

\begin{tabular}{lccc}
\hline Species & \multicolumn{3}{c}{$\%$ predicted $^{\mathrm{a}}$} \\
\cline { 2 - 4 } & Helix & Sheet & Loop \\
\hline Mc. voltae & 36.1 & 27.1 & 36.3 \\
Mc. vannielii & 45.1 & 19.3 & 35.6 \\
Mc. thermolithotrophicus & 26.7 & 27.5 & 45.8 \\
Mc. jannaschii & 22.3 & 25.3 & 51.4 \\
Pc. abyssi & 25.0 & 33.8 & 41.2 \\
Pc. horikoshii & 21.2 & 32.6 & 46.2 \\
Ms. mazei & 4.9 & 39.4 & 55.7 \\
Mb. thermoautotrophicum MTH719 & 14.3 & 38.9 & 46.9 \\
Mt. fervidus & 10.1 & 40.0 & 49.9 \\
Ag. fulgidus AF1413 & 10.6 & 40.2 & 49.2 \\
St. marinus & 14.5 & 45.5 & 40.0 \\
Ha. japonica & 5.7 & 29.8 & 64.5 \\
\hline
\end{tabular}




\begin{tabular}{llll}
\hline Hb. halobium & 7.0 & 30.6 & 62.3 \\
Hf. volcanii & 8.2 & 34.5 & 57.3 \\
\hline a predicted with PHD program; genus abbreviation cf. Table 6 &
\end{tabular}

Thermal stabilization of S-layer proteins has been attributed to posttranslational modifications (e.g. glycosylation), covalent cross-linking or salt-bridging (ENGEL-HARDT and PETERS, 1998). However, the limited number of crystal structures from thermophiles and extreme ther-mophiles has hampered detailed structural comparisons with mesophiles. HANEY et al., (1999) compared the sequences of 115 proteins (S-layer proteins were not included) of Methanococcus jannaschii with their homologues from mesophilic Methanococcus species. The properties mostly correlated with the proteins of the thermophiles included higher residue volume and residue hydrophobic -ity, more charged amino acids (especially glutamic acid, lysine and arginine) and fewer uncharged polar residues (serine, threonine, asparagine and glutamine). In a similar study a high number of proteins from mesophilic and (extremely) thermophilic Bacillus and Methanococcus species were compared (MCDONALD et al., 1999). The authors found an increase of isoleucine, glutamic acid, lysine, arginine and a decrease in methionine, asparagine, glutamine, serine and threonine in the thermophilic methanococcal proteins. In recent studies the complete genome sequences of mesophiles and thermophiles were analysed (CAMBILlau and Claverie, 2000; DAS and GER-STEIN, 2000; ChAKRAVARTY and VARADARAJAN, 2000). A large difference between the proportions of charged versus polar (noncharged) amino acids was found to be a common signature of all hyperthermophilic organisms. As pointed out by CAMBILLAU and CLAVERIE (2000) and DAS and GERSTEIN (2000) the equal increase of oppositely charged residues in hyperthermophiles results from a thermodynamic advantage because of the increased stability of coulombic interactions with temperature. Also HANEY et al. (1999) discussed ionic interactions as a mechanism for thermostabilization of proteins. Electrostatic interactions are important for S-layer stability in extreme halophiles (SUMPER, 1993) as well in other bacteria (SÁRA and SLEYTR, 1987, 2000). Similarly the histones from mesophilic (Methanobacterium formicicum), thermophilic (Methanobacterium thermoautotrophicum) and extremely thermophilic (Methanothermus fervidus) archaea which have similar amino acid sequences, but very different thermodynamic stabilities (LI et al., 2000; TABASSUM et al., 1992) are stabilized by buried intramolecular arginine-aspartate interactions and intramolecular salt bridges on the surface of histone dimers. This tendency holds also for the S-layer proteins of methanococci (AKÇA et al., 2002). In our study we found an increase of charged residues and a reduction of polar residues in the S-layer proteins of the thermophilic and hyperthermophilic species as compared to their mesophilic counterparts. As the overall hydrophobicity was even higher in the mesophilic strains it seems not to play a major role for adaptation to higher temperatures in the case of Methanococcus thermolithotrophicus and Methanococcus jannaschii. Similarly, an increase of solvent accessible surfaces in hyperthermophilic proteins was observed in the study of CAMBILLAU and CLAVERIE (2000).

Thus, the increase in charged amino acids, especially of lysine, as found in thhhhe S-layer proteins of Methanococcus thermolithotrophicus and Methanococcus jannaschii could contribute to their increased thermal stability. Similarly, an increase in charged residues can be observed in the S-layer proteins of Methanosarcina mazei (mesophilic) > Methanobacterium thermoautotrophicum (thermophilic) > Methanothermus fervidus (extremely thermophilic) and Archaeoglobus fulgidus (extremely thermophilic). Interestingly, the S-layer glycoprotein of Methanothermus fervidus contains high amounts of as-paragine (BRÖCKL et al., 1991) and a basic isoelectric point as proved by isoelectric focusing.

A significant feature of the S-layer protein from Methanococcus jannaschii (AKÇA et al., 2002) and other extreme thermophiles (Table 3 ) is the occurrence of cysteine which has been detected in only few S-layer proteins (SÁRA and SLEYTR, 2000). Intra- or intermolecular disulfide-bridges may be another factor involved in the thermal stability of thermophilic surface proteins.

Based on data from the literature (THOMM, 1996) we propose signal sequences for transcription and translation of the S-layer genes of methanococci (AKÇA et al., 2002; Table 7). The promotor sequence (TATA-box, boxA; DNA-dependent RNA-polymerase binding region) and the BRE-box (transcription factor B recognition element) correspond largely to the proposed consensus sequences of methanogenic archaea (THOMM, 1996). In contrast to Methanococcus jannaschii, several tandem promotors have been described for the S-layer gene of Methanococcus voltae (KANSY et al. 1994). The proposed ribosome binding site 5'-AGGAGAU-3', usually located 3-9 nucleotides in front of the translation start point (DALGAARD and GARRET, 1993), was found to be complementary to a region at the 3' terminus of the $16 \mathrm{~S}$ rRNA of Methanococcus jannaschii. Translation of Methanococcus jannaschii and Methanococcus thermolithotrophicus is supposed to terminate with 8 and 3 stop codons, respectively. A series of stop codons is a common feature of methanogenic archaea (DALGAARD and 
GARRETT 1993). The data from the literature (BuLT et al. 1996) show that in the case of Methanococcus jannaschii the stop codons are followed by a poly A/poly T sequence (nucleotides 1729-1877), which probably leads to the formation of a hair-pin and termination of transcription.

Table 6. Comparison of the deduced amino acid sequence of archaeal S-layer proteins ${ }^{1)}$.

\begin{tabular}{|c|c|c|c|c|c|c|c|c|c|c|c|c|c|c|}
\hline $\begin{array}{l}\text { Species with S-layers } \\
\text { genes }\end{array}$ & $\begin{array}{l}\text { Mc. } \\
\text { vol. }\end{array}$ & $\begin{array}{l}\text { Mc. } \\
\text { van. }\end{array}$ & $\begin{array}{c}\text { Mc. } \\
\text { lit. }\end{array}$ & $\begin{array}{l}\text { Mc. } \\
\text { jan. }\end{array}$ & $\begin{array}{l}P c . \\
a b y .\end{array}$ & $\begin{array}{l}\text { Pc. } \\
\text { hor. }\end{array}$ & $\begin{array}{l}\text { Ms. } \\
\text { max. }\end{array}$ & $\begin{array}{l}M b . \\
\text { the. }\end{array}$ & $\begin{array}{l}\text { Mt. } \\
\text { fer. }\end{array}$ & $\begin{array}{l}\text { Ag- } \\
\text { ful. }\end{array}$ & $\begin{array}{l}\text { St. } \\
\text { the. }\end{array}$ & $\begin{array}{l}\mathrm{Ha} . \\
\text { jap. }\end{array}$ & $\begin{array}{l}H b . \\
h a .\end{array}$ & $\begin{array}{l}\text { Hf. } \\
\text { vol. }\end{array}$ \\
\hline Mc. voltae & & $\begin{array}{c}44 \\
(59)\end{array}$ & $\begin{array}{c}48 \\
(61)\end{array}$ & $\begin{array}{c}38 \\
(54)\end{array}$ & $\begin{array}{c}23 \\
(38)\end{array}$ & $\begin{array}{c}28 \\
(44)\end{array}$ & - & - & - & - & - & - & - & - \\
\hline Mc. vannielii & $\begin{array}{c}47 \\
(60)\end{array}$ & & $\begin{array}{c}49 \\
(62)\end{array}$ & $\begin{array}{c}44 \\
(59)\end{array}$ & $\begin{array}{c}24 \\
(38)\end{array}$ & $\begin{array}{c}31 \\
(45)\end{array}$ & - & - & - & - & - & - & - & - \\
\hline $\begin{array}{l}\text { Mc. thermolitho- } \\
\text { trophicus }\end{array}$ & $\begin{array}{c}50 \\
(63)\end{array}$ & $\begin{array}{c}49 \\
(61)\end{array}$ & & $\begin{array}{c}53 \\
(69)\end{array}$ & $\begin{array}{c}26 \\
(41)\end{array}$ & $\begin{array}{c}29 \\
(41)\end{array}$ & - & - & - & - & - & - & - & - \\
\hline Mc. jannaschii & $\begin{array}{c}40 \\
(56)\end{array}$ & $\begin{array}{c}44 \\
(60)\end{array}$ & $\begin{array}{c}53 \\
(69)\end{array}$ & & $\begin{array}{c}25 \\
(37)\end{array}$ & $\begin{array}{c}23 \\
(49)\end{array}$ & - & - & - & - & - & - & - & - \\
\hline Pc. abyssi & $\begin{array}{c}24 \\
(39)\end{array}$ & $\begin{array}{c}25 \\
(39)\end{array}$ & $\begin{array}{c}26 \\
(41)\end{array}$ & $\begin{array}{c}26 \\
(40)\end{array}$ & & $\begin{array}{c}79 \\
(81)\end{array}$ & - & - & - & - & - & - & - & - \\
\hline Pc. horikoshii & $\begin{array}{c}27 \\
(41)\end{array}$ & $\begin{array}{c}32 \\
(45)\end{array}$ & $\begin{array}{c}29 \\
(41)\end{array}$ & $\begin{array}{c}29 \\
(46)\end{array}$ & $\begin{array}{c}79 \\
(87)\end{array}$ & & - & - & - & - & - & - & - & - \\
\hline Ms. mazei & - & - & - & - & - & - & & $\begin{array}{c}28 \\
(43)\end{array}$ & $\begin{array}{c}30 \\
(40)\end{array}$ & $\begin{array}{c}28 \\
(42)\end{array}$ & - & - & - & - \\
\hline $\begin{array}{l}\text { Mb. thermoauto- } \\
\text { trophicum MTH719 }\end{array}$ & - & - & - & - & - & - & $\begin{array}{c}26 \\
(43)\end{array}$ & & $\begin{array}{c}30 \\
(40)\end{array}$ & $\begin{array}{c}27 \\
(41)\end{array}$ & - & - & - & - \\
\hline Mt. fervidus & - & - & - & - & - & - & $\begin{array}{c}26 \\
(36)\end{array}$ & $\begin{array}{c}28 \\
(38)\end{array}$ & & $\begin{array}{c}37 \\
(59)\end{array}$ & - & - & - & - \\
\hline Ag. fulgidus AF 1413 & - & - & - & - & - & - & $\begin{array}{c}26 \\
(41)\end{array}$ & $\begin{array}{c}34 \\
(50)\end{array}$ & $\begin{array}{c}25 \\
(40)\end{array}$ & & - & - & - & - \\
\hline St marinus & - & - & - & - & - & - & - & - & - & - & & - & - & - \\
\hline Ha. japonica & - & - & - & - & - & - & - & - & - & - & - & & $\begin{array}{c}52 \\
(66)\end{array}$ & $\begin{array}{c}40 \\
(56)\end{array}$ \\
\hline Hb. halobium & - & - & - & - & - & - & - & - & - & - & - & $\begin{array}{c}46 \\
(59)\end{array}$ & & $\begin{array}{c}83 \\
(83)\end{array}$ \\
\hline Hf. volcanii & - & - & - & - & - & - & - & - & - & - & - & $\begin{array}{c}38 \\
(53) \\
\end{array}$ & $\begin{array}{c}37 \\
(53) \\
\end{array}$ & \\
\hline
\end{tabular}

${ }^{1)}$ Alignments of amino acid sequences (BLAST 2.0). Data are given as numbers of identity or similarity values (brackets) of the aligned regions. - no significant homology found by BLAST 2.0; Genus abbreviation: Ag. Archaeoglobus; Ha. Haloarcula; Hb. Halobacterium; Hf. Haloferax; Mb. Methanobacterium, Mc. Methanococcus, Ms. Methanosarcina, Mt. Methanothermus; Pc. Pyro-coccus, St. Staphylothermus.

Table 7. Presumptive signal sequences for transcription and translation of the S-layer genes of methanococci.

\begin{tabular}{|c|c|c|c|}
\hline Gene recognition site & Sequence & Position & Consensus-Sequence $^{(1)}$ \\
\hline \multicolumn{4}{|l|}{ Promotor } \\
\hline \multicolumn{4}{|l|}{ a. BRE-Box: } \\
\hline$M j(\mathrm{MJ} 0822)$ & -CGTAA- & $-33--29$ & -CGAAA- \\
\hline$M t(\mathrm{AJ} 308554)$ & -GGAAA- & $-35--31$ & \\
\hline Mva (AJ308553) & -GGAAA- & $-40--36$ & \\
\hline \multicolumn{4}{|l|}{ b. TATA-Box: } \\
\hline$M j$ & -TTTATATA- & $-26--19$ & -AA/TT TATATA- \\
\hline$M t$ & -TATATATA- & $-28--21$ & \\
\hline$M v$ & -TATAATAA- & $-32--25$ & \\
\hline \multicolumn{4}{|l|}{ c. Transcription start: } \\
\hline$M j$ & -ATAC- & 1 & A/TTGC \\
\hline$M t$ & -ATCC- & 1 & \\
\hline$M v a$ & -ATAC- & 1 & \\
\hline \multicolumn{4}{|c|}{ Shine-Dalgarno-Sequence: } \\
\hline$M j$ & -AGGTGAT- & $33-39$ & \\
\hline$M t$ & -AGGGTGA- & $64-70$ & \\
\hline
\end{tabular}




\begin{tabular}{lcc}
\hline$M v a$ & -AGGTGAA- & $60-66$ \\
Translation start: & & \\
$M j$ & -ATG- & 45 \\
$M t$ & -ATG- & 77 \\
$M v$ & -ATG- & 72 \\
\hline
\end{tabular}

T) according to Thomm (1996); Mj - Methanococcus jannaschii; Mt - Methanococcus thermolithotrophicus, Mva - Methanococcus vannielii; Accession no. of the corresponding genes: Mj (MJ0822), Mt (AJ308554), Mva (AJ308553).

Fig. 1. Micrograph of some crystals inside a HD-reactor. Arrow: crystal used for the determination of the cell parameters mentioned in the text.

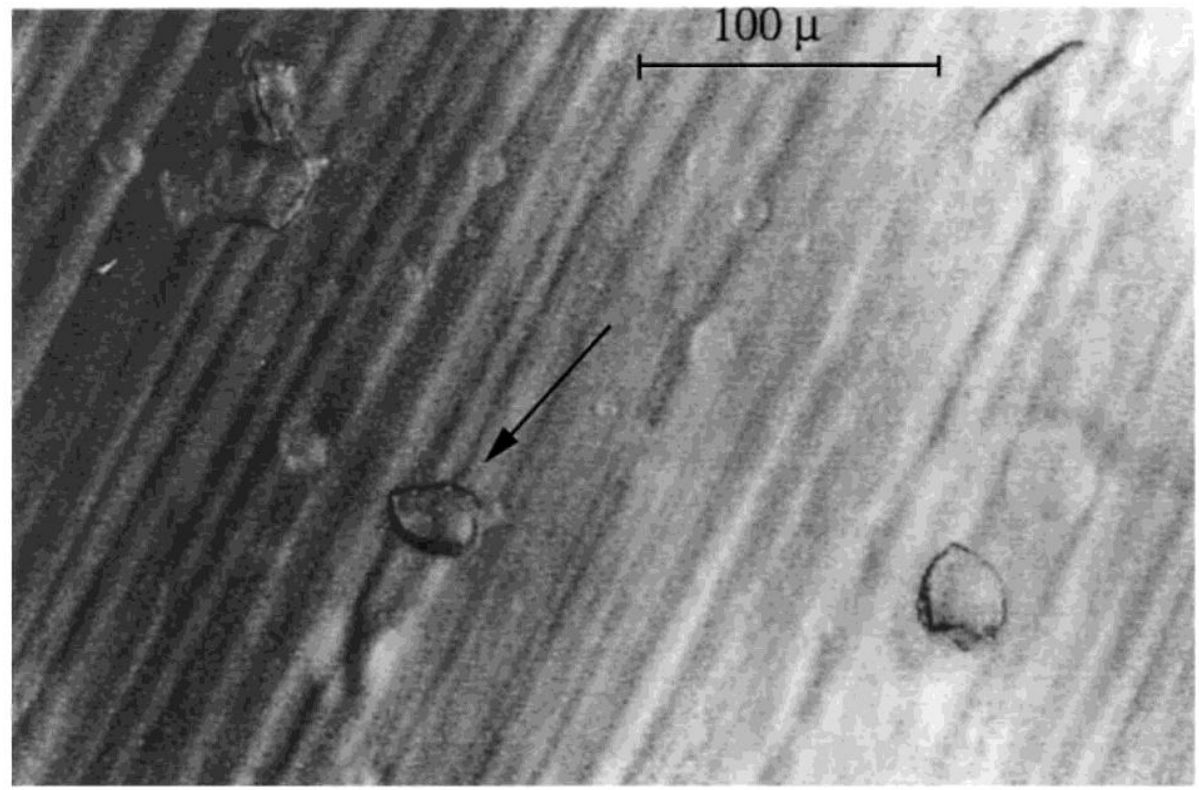

In general, only minor structural differences were observed in the primary and secondary structures of the Slayer proteins of mesophilic and extremely thermophilic methanococci. One important point to consider is that the ancestor of Methanococcales was probably a ther-mophile (KESWANI et al., 1996). This pattern supports the hypothesis that mesophily is a modern adaptation and thermophilic structures are still conserved in mesophilic proteins, especially S-layer proteins. An exchange of an amino acid in mesophilic proteins may then be simply the result of a relaxation of selection against this amino acid which may be of importance in the extremely thermophilic counterparts (MCDONALD et al., 1999).

\section{CRYSTALLIZATION UNDER MICROGRAVITY CONDITIONS}

Methanothermus fervidus has been isolated from Icelandic hot solfatara field (STETTER et al., 1981). It possesses an S-layer outside of the pseudomurein sacculus. The gene $(\operatorname{slg} \mathrm{A})$ encoding the S-layer glycoprotein has been sequenced (BRÖCKL et al., 1991) and the chemical structure of the heterosaccharide has been elucidated (KÄRCHER et al., 1993). The mature peptide is predicted to consist of 593 amino acids resulting in a molecular mass of $65 \mathrm{kDa}$ (BRÖCKL et al., 1991). With mass spectrometry (MALDI) a molecular mass of $83 \mathrm{kDa}$ was determined for the mature glycoprotein indicating that the glycan moiety accounts for $22 \%$.

Methanothermus fervidus grows optimally at $85{ }^{\circ} \mathrm{C}$ and the S-layers may serve a models to elucidate the molecular strategies for survival at high temperatures. For X-ray analysis it is essential to obtain crystals with high quality. Crystal growth under microgravity conditions is advantageous, since it overcomes certain difficulties. The first crystallization experiments were conducted under microgravity conditions (EVRARD et al., 1999) using the Advanced Protein Crystallization Facilities developed by Dornier. The crystals were succesfully grown during the flight STS-95 of the space shuttle Discovery. Hanging drop reactors (HD-80) were used. One of the crystals with dimensions of $30 \times 20 \times 5 \mu \mathrm{m}$ were selected for X-ray analysis (Fig. 1). The diffraction experiments were performed at the EMBL DESY synchroton facility in Hamburg. Diffraction spots were 
observed to a resolution of $4.2 \AA$. Cell parameters were: $a=232.6, b=55.9, c=144.3 \AA, \beta=129^{\circ}$. The crystal system is monoclinic and has the space group $\mathrm{C} 2$. Meanwhile, we also observed crystals from S-layer proteins of other prokaryotic species with dimensions of up to $224 \mu \mathrm{m}$ (unpublished results).

\section{Acknowledgments}

We would like to thank the "Ministerium für Bildung, Wissenschaft, Forschung und Technologie" and the "Deutsches Zentrum fur Luft- und Raumfahrt" (Bonn, Germany), the "EMBL" (DESY facilities, Hamburg) and the "Services Fédéraux des Affaires Scientifiques Techniques et Culturelles" (Brussels, Belgium) for supporting this work.

\section{References}

AkÇa, E., Claus, H., Schultz, N., Karbach, G., Schlott, B., DebaerdemaeKer, T., DeclercQ J.-P., König, H.: Genes and derived amino acid sequences of S-layer proteins isolated from mesophilic, thermophilic and extremely thermophilic methanococci. Extremophiles. In press (2002)

BAUMEISTER, W. VOLKer, S., SANTARIUS, U.: The three-dimensional structure of the surface protein of Acidianus brierleyi determined by electron crystallography. System. Appl. Microbiol. 14,103-110(1991).

BAUMEISTER, W., LEMBCKE, G.: Structural features of archaebacterial cell envelopes. J. Bioenerg. Biomembr. 24, 567-575 (1992).

Bayley, D. P., Koval, S. F.: Membrane association and isolation of the S-layer protein of Methanoculleus marisnigri. Can. J. Microbiol. 40, 237-241 (1994).

BEVERIDGE, T. J., GRAHAM, L. L.: Surface layers of bacteria. Microbiol. Rev. 55, 684-705 (1991).

Beveridge, T. J., Koval, S. F. (eds.): Advances in Paracrystalline Bacterial Surface Layers. New York, Plenum Press 1993.

BEVERIDGE, T. J., and 33 other authors: Functions of S-layers. FEMS Microbiol. Rev. 20, 99-149 (1997).

Boot, H. J., Pouwels, P. H.: Expression, secretion and antigenic variation of bacterial S-layer proteins. Mol. Microbiol. 21, 11171123(1996).

BröCKL, G., Behr, M., FABRY, M., Hensel, R., KAudewitz, FL, BIEndl, E., KöNIG, H.: Analysis and nucleotide sequence of the genes encoding the surface-layer glycoproteins of the hy-perthermophilic methanogens Methanothermus fervidus and Methanothermus sociabilis. Eur. J. Biochem. 199, 147-152 (1991).

BULT, C. J., and 39 other authors: Complete genome sequence of the methanogenic archaeon, Methanococcus jannaschii. Science 273, 1058$1072(1996)$

Cambillau, C, Claverie, J. M.: Structural and genomic correlates of hyperthermostabilty. J. Biol. Chem. 275, 32383-32386 (2000).

CHAKRAVARTTY, S., VARADARAJAN, R.: Elucidation of determinants of protein stability through genome sequence analysis. FEBS Lett. 470, 65-69 (2000).

DAlgaARD, J. Z., GARRETT, R. A: Archaeal hyperthermophile genes, pp. 535-563. In: The Biochemistry of Archaea (Archae-bacteria) (M. Kates, D. J. Kushner, T. A. Matheson, eds). Amsterdam, Elsevier 1993.

DAS, R., GERSTEIN, M.: The stability of thermophilic proteins: a study based on comprehensive genome comparison. Funct. Integr. Genomics 1, 76-88 (2000).

Deathrage, J. F, TAYlor, K. A., Amos, L. A.: Three-dimensional arrangement of the cell wall protein of Sulfolobus aci-docaldarius.). Mol. Biol. 167, 823-848 (1983).

Egelseer, E.M., DANHORn, D., Pleschberger, M, Hotzy, C, SLEyTR, U.B., SÁRA M.: Characterization of an S-layer glycoprotein produced in the course of S-layer variation of Bacillus stearothermophilus ATCC 12980 and sequencing and cloning the sbsD gene encoding the protein moiety. Arch. Microbiol. 177, 70-80 (2001)

ENGELHARDT, FL, PETERS, J.: Structural research on surface layers: a focus on stability, surface layer domains, and surface layer-cell wall interactions. J. Struct, Biol, 124, 276-302 (1998)

Evrard, Ch, DeClercQ, J.-R, DeBAerdemaeKer, T, KÖNIG H.: The first successful crystallization of a prokaryotic extremely thermophilic outer surface layer glycoprotein. Z. Kristallogr. 214,427-429(1999).

Fiala, G., Stetter, K.: Pyrococcus furiosus sp. nov. represents a novel genus of marine heterotrophic archaebacteria growing optimally at $100{ }^{\circ} \mathrm{C}$. Arch. Microbiol. 145, 56-61 (1986). 
Haney, P.J., BAdger, J. FL, Buldak, G. L., Reich, C. I., Woese, C. R., OlsEN, G. J.: Thermal adaption analyzed by comparison of protein sequences from mesophilic and extremely thermophilic Methanococcus species. Proc. Natl. Acad. Sci. USA 96,3578-3583 (1999).

KANDLER, O., KÖNIG, H.: Chemical composition of the peptido-glycan-free cell walls of methanogenic bacteria. Arch. Microbiol. 118, 141$152(1978)$

KAndleR, O., KÖNIG, H.: Cell envelopes of archaebacteria. pp. 413-457. In: The Bacteria. A Treatise on Structure and Function. Archaebacteria. (C. R. Woese, R. S. Wolfe, eds.) Vol. VIII, New York, Academic Press 1985.

KANDLER, O., KÖNIG, H.: Cell envelopes of archaea: structure and chemistry, pp. 223-259. In: The Biochemistry of Archaea (Archaebacteria) (M. Kates, D. J. Kushner, A. T. Matheson, eds.). Amsterdam,. Elsevier Science Publishers 1993.

Kansy, W. J., Carinato, M.E., Monteggia, L.M., Konisky, J.: In vivo transcripts of the S-layer encoding structural gene of the archaeon Methanococcus voltae. Gene 148, 131-135 (1994)

Karlson, P., Doeneckce, D., Koolman, J.: Kurzes Lehrbuch der Biochemie für Mediziner und Naturwissenschaftler. Stuttgart, G. Thieme Verlag 1994.

KÄrcher, U., SchröDer, H., Haslinger, E., Allmaier, G., Schreiner, R., Wieland, E, Haselbeck, A., König, H.: Primary structure of the heterosaccharide of the surface glycoprotein of Methanothermus fervidus. J. Biol. Chem. 268, 26821-26826(1993).

Keswani, J., Orkand, S., Premachandran, U., Mandelco, L., Frankiln, M. J., Whitman, W. B.: Phylogeny and taxonomy of mesophilic Methanococcus spp. and comparison of rRNA, DNA hybridization, and phenotypic methods. Int. J. System. Bact. 46, 727735(1996).

KÖNIG, H.: Chemical composition of cell envelopes of methanogenic bacteria isolated from human and animal feces. System. Appl. Microbiol. 8, 159-162 (1986).

KÖNIG, H., STETTER, K. O.: Isolation and characterization of Methanolobus tindarius, sp. nov., a coccoid methanogen growing only on methanol and methylamines. Zbl. Bakt. Hyg., I. Abt. Ong. C 3, 478-490 (1982).

KÖNIG, H., MESSNER, P. (eds.). International Workshop on Structure, Biochemistry, Molecular Biology and Applications of Microbial SLayers. Special Issue. FEMS Microbiol. Rev. 20, Vol. 1 +2 (1997).

KÖNIG H., Kralik, R., KANDlER, O.: Structure and modifications of pseudomurein in Methanobacteriales. Zbl. Bakt. Hyg., I. Abt. Ong. C 3, 179-191 (1982)

Kreisl, P., KANDLER, O.: Chemical structure of the cell wall polymer of Metbanosarcina. Syst. Appl. Microbiol. 7, 293-299 (1986).

KurR, M., Huber, R., König, H., Jannasch, H. W, Fricke, H., Trincone, A., Kristuannson, J. K., StetTer, K. O.: Methanopyru s kandleri, gen. and sp. nov. represents a novel group of hyperthermophilic methanogens, growing at $110^{\circ} \mathrm{C}$. Arch. Microbiol. $156,239-247$ (1991).

LECHNER, J., SUMPER, M.: The primary structure of a procaryotic glycoprotein. Cloning and sequencing of the cell surface glycoprotein gene of halobacteria. J. Biol. Chem. 262, 9724-9729 (1987).

LI, W.T., SHRIVER, J. W, REEVE, J. N.: Mutational analysis of differences in thermostability between histones from mesophilic and hyperthermophilic archaea. J. Bacteriol. 182, 812-817 (2000).

Mayerhofer, L. E., Conway de Macario, E., YaO, R., MACARIO, A.J.: Structure, organization, and expression of genes coding for envelope components in the archaeon Metbanosarcina mazei S-6. Arch. Microbiol. 169, 339-45 (1998).

McDonald, J.H., Grasso, A. M., Rejto, L. K.: Patterns of temperature adaptation in proteins from Methanococcus and Bacillus. Mol. Biol. Evol. 16, 1785-1790 (1999).

Messner, P., SLEYtR, U. B.: Crystalline bacterial cell surface layers. Adv. Microb. Physiol. 33, 213-275 (1992).

Messner, P., Pum, D., SÁRA, M., STETTER, K. O., Sleytr, U. B.. Ultrastructure of the cell envelope of the archaebacteria Tber-moproteus tenax and Tbermoproteus neutropbilus. J. Bacteriol. 166,1046-1054 (1986).

Niemetz, R., Kärcher, U., KAndLER, O., Tindall, B. J., KÖNIG, H.: The cell wall polymer of the extremely halophilic archaeon Natronococcus occultus. Eur. J. Biochem. 249, 905-911 (1997).

Nielsen, H., Engelbrecht, J., BRUnAK, S., VON HeIJNE, G.: Identification of prokaryotic and eukaryotic signal peptides and prediction of their cleavage sites. Protein Eng. 10, 1-6 (1997)

PAtel, G. B., SPROtT, G. D.: Methanosaeta concilii gen. nov., sp. nov., („Methanotbrix concilii") and Methanosaeta thermoacetophila nom. rev., comb. nov. Int. J. Syst. Bacteriol. 40, 79-82 (1990). 
Peters, J., Nitsch, M., Kuehlmorgen, B., Golbik, R., Lupas, A., Kellermann, J., Engelhardt, H. Pfander, J. P., Mueller, S., GOLDIE, K., ENGEL, A., STETTER, K. O., BAUMEISTER, W:Tetrabrachion: A filamentous archaebacterial surface protein assembly of unusual structure end extreme stability. J. Mol. Biol. 245, 385-401 (1995).

PHIPPS, B. M., HUBER, R., BAUMEISTER, W: The cell envelope of the hyperthermophilic archaebacterium Pyrobaculum organotrophum consists of two regularly arrayed protein layers: three-dimensional structure of the outer layer. Mol. Microbiol. 5, 253-265 (1991)

SÁRA, M., SLEYTER, U. B.: Charge distribution on the S-layer of Bacillus stearotbermopbilus NRS 1536/3c and importance of charged groups for morphogenesis and function. J. Bacteriol. 169, 2804-2809(1987).

SÁRA, M., SLEYTER, U. B.: S-layer proteins. J. Bacteriol. 182, 859-868 (2000).

SCHÄFER, C, MESSNER, P.: Glycobiology of surface layer proteins. Biochimie 83, 591-599 (2001).

SCHLEIFER, K. H., SteBer, J., MaYer, H.: Chemical composition and structure of the cell wall of Halococcus morrbuae. Zbl. Bakt., Hyg., I. Abt. Ong. C3, 171-178 (1982).

SLEYTR, U.B.: Basic and applied S-layer research: an overview. FEMS Microbiol. Rev. 20, 5-12 (1997).

Sleytr, U. B., BeVERIDGe, T. J.: Bacterial S-layers. Trends in Microbiol. 7, 253-260 (1999).

Southam, G., Firtel, M., Blackford, B. L., Jericho, M. H., Xu, W, Mulhern, P. J., Beveridge, T. J.: Transmission electron microscopy, scanning tunneling microscopy, and atomic force microscopy of the cell envelope layers of the ar-chaeobacterium Methanospirillum hungatei GP1. J. Bacteriol. 175, 1946-1955(1993).

STETTER, K. O.: The genus Archaeoglobus, p.707-711. In: The Prokaryotes. A Handbook of Bacteria: Ecophysiology, Isolation, Identification, Applications, 2nd Ed. (A. Balows, H. G. Trüper, M. dworkin, W Harder, K.-H. Schleifer, eds.)Vol. 1. Berlin, Springer-Verlag 1992.

Stetter, K.O., Thomm, M., Winter, J., Wildgruber, G., Huber, H., Zillig, W, Janecovic, D., König, H., Palm, P., WUNDERL, S. Metbanotbermus fervidus, sp. nov., a novel extremely thermophilic methanogen isolated from an Icelandic hot spring. Zbl. Bakt. Hyg., I. Abt. Ong. C 2, 166-178 (1981)

StetTer, K. O., KÖNIG, H., StackebrandT, E.: Pyrodictium gen. nov., a new genus of submarine disc-shaped sulphur reducing archaebacteria growing optimally at $105^{\circ}$ C. System. Appl. Microbiol. 4, 535-551 (1983).

Stetter, K. O., Thomm, M., Winter, J., Wildgruber, G., Huber, H., Zillig, W, Janecovic, D., König, H., Palm, P., Wunderl, S.: Metbanotbermus fervidus, sp. nov., a novel extremely thermophilic methanogen isolated from an Icelandic hot spring. Zbl. Bakt. Hyg., I. Abt. Ong. C 2, 166-178 (1981)

SUMPER, M.: S-layer glycoproteins from moderately and extremely halophilic archeobacteria, p. 109-117. In: Advances in Bacterial Paracrystalline Surface Layers (T.J. Beveridge, S.F. Koval, eds.), (NATO ASI Series A: Life Sciences) Vol. 252. New York, Plenum Press 1993.

SuMPER, M., WiEland, F. T.: Bacterial glycoproteins, pp. 455-473. In: Glycoproteins (J. Montreuil, J. F. G. Vliegenthart, H. Schachter, eds.). Amsterdam, Elsevier 1995

Sumper, M., Berg, E., Mengele, R., Strobel, I.: Primary structure and glycosylation of the S-layer protein of Haloferax volcanii. J. Bacterid. 172, 7111-7118 (1990)

TABAssum, R., K., SANDMAN, K. M., REEVE, J. N.: HMt, a his-tone-related protein from Methanobacterium thermoautotrophicum. J. Bactenol. 174, 7890-7895 (1992)

THомм, M.: Archaeal transcription factors and their role in transcription inititation. FEMS Microbiol. Rev. 18, 159-171 (1996).

Wakai, H., NaKamura, S., Kawasaki, FL, TAKada, K., Mizu-Tani, S., Aono, R., Horikoshi, K.: Cloning and sequencing of the gene encoding the cell surface glycoprotein of Haloarcula japonica strain TR-1. Extremophiles 1, 29-35 (1997).

Wildgruber, G., Thomm, M., KöNig, H., OBer, K., Ricchiuto, T, STETTER, K. O.: Methanoplanus limicola, a platesphaped methanogen representing a novel family, the Methano-planaceae. Arch. Microbiol. 132, 31-36 (1982).

WILDHABER, I., SANTARIUS, U., BAUMEISTER, W.: Three-dimensional structure of the surface protein of Desulfurococcus mobilis. J. Bactenol. 169, 5563-5568 (1987)

YANG, L. L., HAUG, A.: Purification and partial characterization of a procaryotic glycoprotein from the plasma membran of Thermoplasma acidophilum. Biochim. Biophys. Acta 556, 277-365(1979).

Zellner, G., Alten, G., Stackebrandt, E., Conway de Macario, E., Winter, J.: Isolation and characterization of Methanocorpusculum parvum, gen. nov. spec, nov., a new tungsten requiring, coccoid methanogen. Arch. Microbiol. 147, 13-20 (1987) 
Published in :Systematic \& Applied Microbiology (2002)

Status: Postprint (Author's version)

Zellner, G., Messner, P., Kneifel, FL, Tindall, B. J., Winter, J., StackBrandt, E.: Methanolacinia gen. nov., incorporating Methanomicrobium paynteri as Methanolacinia paynteri comb. nov. J. Gen. Appl. Microbiol. 35, 185-202 (1989).

Zillig, W., Holz, I., Janekovic, D., Klenk, Fl P., Imsel, E., Trent, J., Wunderl, S., ForjaZ, V. FL, Coutinho, R., Fer-Reira, T.: Hyperthermus butylicus, a hyperthermophilic sulfur-reducing archaebacterium that ferments peptides. J. Bactenol. 172, 3959-3965 (1990). 